\title{
Beta-1 Globulin to Total Beta Protein Ratio Measurement
}

National Cancer Institute

\section{Source}

National Cancer Institute. Beta-1 Globulin to Total Beta Protein Ratio Measurement. NCI

Thesaurus. Code C142277.

The determination of the ratio of beta-1 globulin compared to beta protein present in a sample. The measurement may be expressed as a ratio or percentage. 